\title{
PERICLIMENES DENTIDACTYLUS, A NEW DEEP WATER PONTONIINE SHRIMP FROM MAKASSAR STRAIT, INDONESIA
}

\author{
by \\ A.J. BRUCE ${ }^{1}$ )
}

\section{RESUME}

Une nouvelle espece de crevette, pontoniine, Periclimenes dentidactylus est decrite et illustree. L'unique specimen a ete recolte dans le detroit de Makassar a une profondeur de plus de $590 \mathrm{ni}$, une profondeur surpassee par deux especes du genre settlement. P. dentidactylus s'apparente de pres a P. hertwigi Balss et est probablement une associee d'echinoides.

\section{ABSTRACT}

A new species of pontoniine shrimp, Periclimenes dentidactylus is described and illustrated. The single specimen was collected from Makassar Strait from over $590 \mathrm{~m}$, a depth exceeded by only two other species of the genus. P. dentidactylus is closely related to F. hertwigi Balss, and is probably also an echinoid associate.

\section{INTRODUCTION}

Although over 250 species of pontoniine shrimp are now known from the Indo-West Pacific region, as yet comparatively few species have been recorded from water of depths greater than $100 \mathrm{~m}$. The 21 species, of six different genera, have been listed by BRUCE (1981). The discovery of a further species is therefore of interest- The single example was collected by the R.V. "Coriolis" during the 1980 French-Indonesian CORINDON 2 Expedition. I am most grateful to Dr. J. Forest for the opportunity to examine and report upon this specimen.

\section{Periclimenes dentidactyhts sp. nov.}

(Figures 1-6)

Material examined. - CORINDON 2, Stn, 214, 1.11.1980, 0³1, 4'N, 11750,l'E, 592-595 m, beam-trawl: 1 \% .

Description. A medium sized slenderly built pontoniine shrimp.

The carapace is smooth], with a long slender rostrum extending well beyond the antennular peduncle, with the distal position feebly upcurved.

$\left.{ }^{1}\right)$ Division of Natural Sciences, Northern Territory Museum, P.O. Box 4646, Darwin, Australia 5794. 
The dorsal margin bears six subequal acute teeth, with a slightly smaller distal tooth. The first tooth i,s situated over the orbital margin. The distal half of the lower border bears three small acute teeth. The lateral rostral carinae are poorly developed. A small epigastric tubercle is present; supraorbital spines are absent and the orbit is obsolete, but with a well developed acute inferior orbital angle. The antennal spine is well developed, marginal, long and slender, extending well beyond the inferior orbital angle. The hepatic \$pine is very well developed, slender, longer than the antennal spine and situated at a position slightly below and behind the base of the antennal spine, close to the anterior border of the branehiostegite, which has the antero-Jateral angle bluntly rectangular.

The abdominal segments are smooth. The third is not produced postero-dorsally. The fifth segment is about 0.9 of the length of the sixth, which is about 1.5 times longer than deep, with the postero-lateral angle acutely produced and the postero-ventral angle more blunt. The pleura of the first three segments are rounded those of the fourth and fifth segments bluntly produced posteriorly. The telson is about 1.8 times the length of the sixth segment, about 3.2 times longer than wide, tapering to an angular posterior border, about 0.4 of the anterior width with a small acute median point. The dorsal surface bears two pairs of well developed marginal spines at 0.45 and 0.7 of the telson length. The posterior border bears a pair of small lateral spines, rather smaller than the dorsal spines, with well developed intermediate spines, equal to about 0.15 of the telson length and 3.75 times the lateral spines, with smaller short setulose submedian spines, equal to about 0.3 of the intermediate spine length.

The eyes have a large globular cornea, well pigmented with a dorsal accessory pigment spot. The stalk is short, narrower than the cornea and tapering proximally.

The proximal segment of the antennular peduncle has a well developed acute stylocerite that reaches to the midpoint of the medial border. The antero-lateral angle is produced and bears a long slender tooth that reaches to the level of the proximal end of the distal peduncular segment. The ventral medial border of the segment is armed with a small acute tooth at about half its length. The statocyst is normally developed with a subcircular statolith. The intermediate segment is short, about 0.25 of the length of the proximal segment, with a small lateral lobe. The distal segment is about 1.5 times the length of the proximal segment. The 


\section{A NEW DEEP WATER PONTONIINE}

upper flagellum is biramous, with the proximal nine stouter segments fused. The shorter free ramus consists of only three segments. The longer free ramus is slender with about 15 segments. About 20 groups of aesthetascs are present. The lower flagellum is slender, of similar length to the upper- flagellum, with about 25 segments.

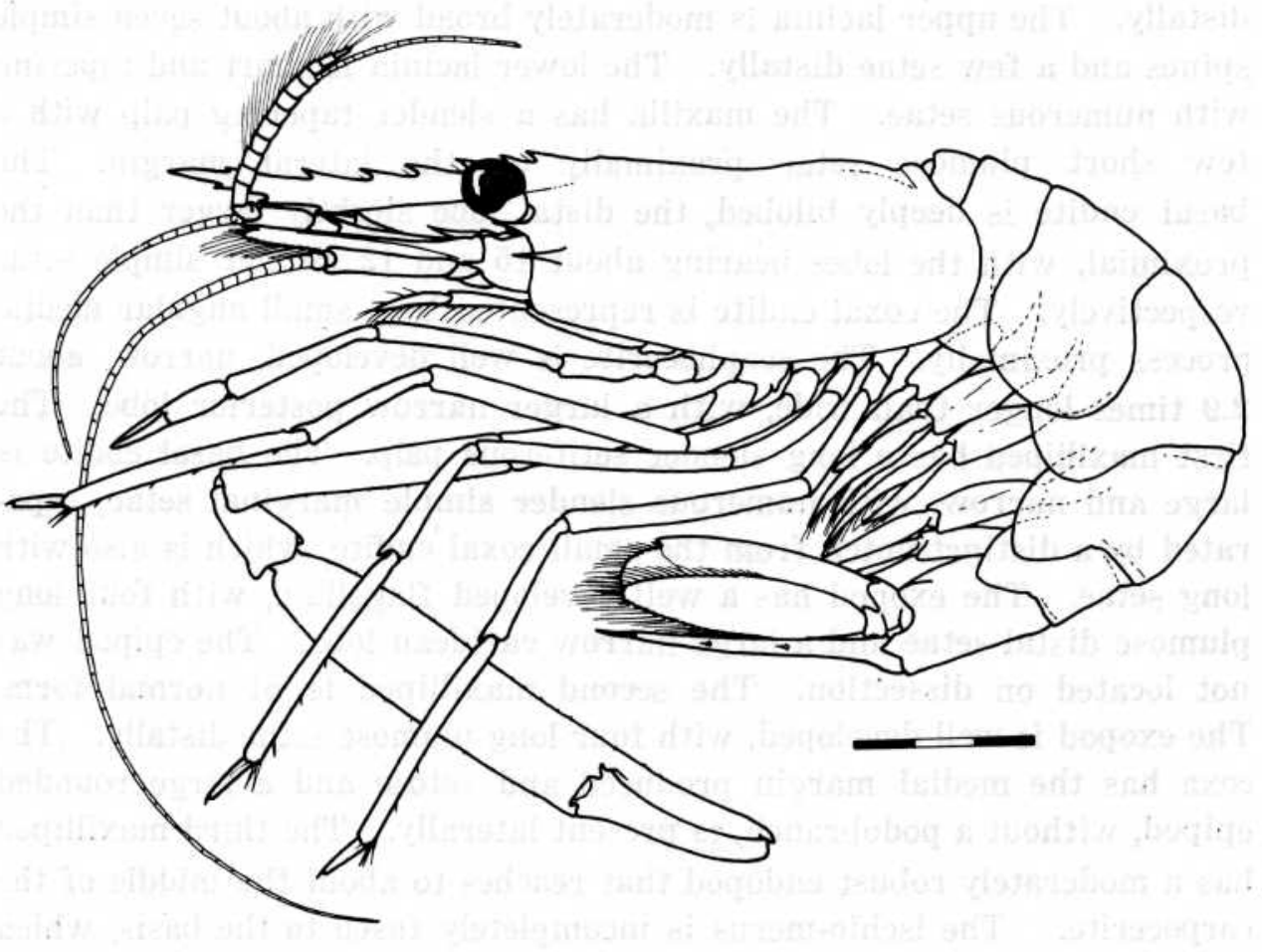

Fig. 1. Periclimenes dentidactylus sp. nov,, holotype, male.

The antenna has a basicerite with a strong disto-lateral tooth. The carpocerite is about 4.5 times longer than wide and reaches a little beyond the middle of the scaphocerite. The flagellum is well developed and slender. The scaphocerite extends to the end of the antennular peduncle and is well exceeded by the rostrum. The lamella is about 3.1 times longer than wide, with the greatest width at about 0.3 of its length, the distal margin bluntly angled, the lateral border straight with a long slender distal tooth extending well beyond the anterior margin of the lamella,

The epistome is unarmed. The thoracic sternites are narrow and the fourth sternite is without a median spine. 
The mouthparts are of the usual form. The mandible is moderately robust and without a palp. The molar process is stout with four large blunt teeth and few setae. The incisor process ends in three acute teeth of which the central is the smallest. The maxillula has a bilobed palp with an elongated upper lobe, the lower lobe with a small simple seta distally. The upper lacinia is moderately broad with about seven simple spines and a few setae distally. The lower lacinia is short and tapering with numerous setae. The maxilla has a slender tapering palp with a few short plumose setae proximally on the lateral margin. The basal endite is deeply bilobed, the distal lobe slightly larger than the proximial, with the lobes bearing about 15 and 12 slender simple setae respectively. The coxal endite is represented by a small angular medial process proximally. The scaphocerite is well developed, narrow, about 2.9 times longer than wide, with a Jarger narrow posterior lobe. The first maxilliped has a long slender setiferous palp. The basal endite is large and narrow, with numerous slender simple marginal setae, .separated by a distinct notch from the small coxal endite, which is also with long setae. The exopod has a well developed flagellum, with four long plumose distal setae and a large narrow ${ }^{\wedge}$ caridean lobe. The epipod was not located on dissection. The second maxilliped is of normal form. The exopod is well developed, with four long plumose setae distally. The coxa has the medial margin produced and setose and a large rounded epipod, without a podobranch, is present laterally. The third maxilliped has a moderately robust endopod that reaches to about the middle of the carpocerite. The ischio-merus is incompletely fused to the basis, which is slightly produced medially. The ischio-meral portion of the antepenultimate segment is about 6.0 times longer than wide, bowed, and rather broadened distally, with numerous slender very finely serrulate setae along the medial border. The penultimate segment is about 4.2 times longer than wide, about 0.6 of the ischio-merus length, with several groups of sparsely serrulate spines medially. The distal segment is about 0.8 of the length of the rpenultimatei, with a strong distal spine and numerous finely serrulate spines ventrally and laterally. The exopod is well developed with fine long plumose distal setae and several .shorter setae. The coxa is produced dnto a small medial lobe and bears a small rounded epipod laterally. A small multi-lamellar arthrobranch is present. 
A NEW DEEP WATER PONTONIINE

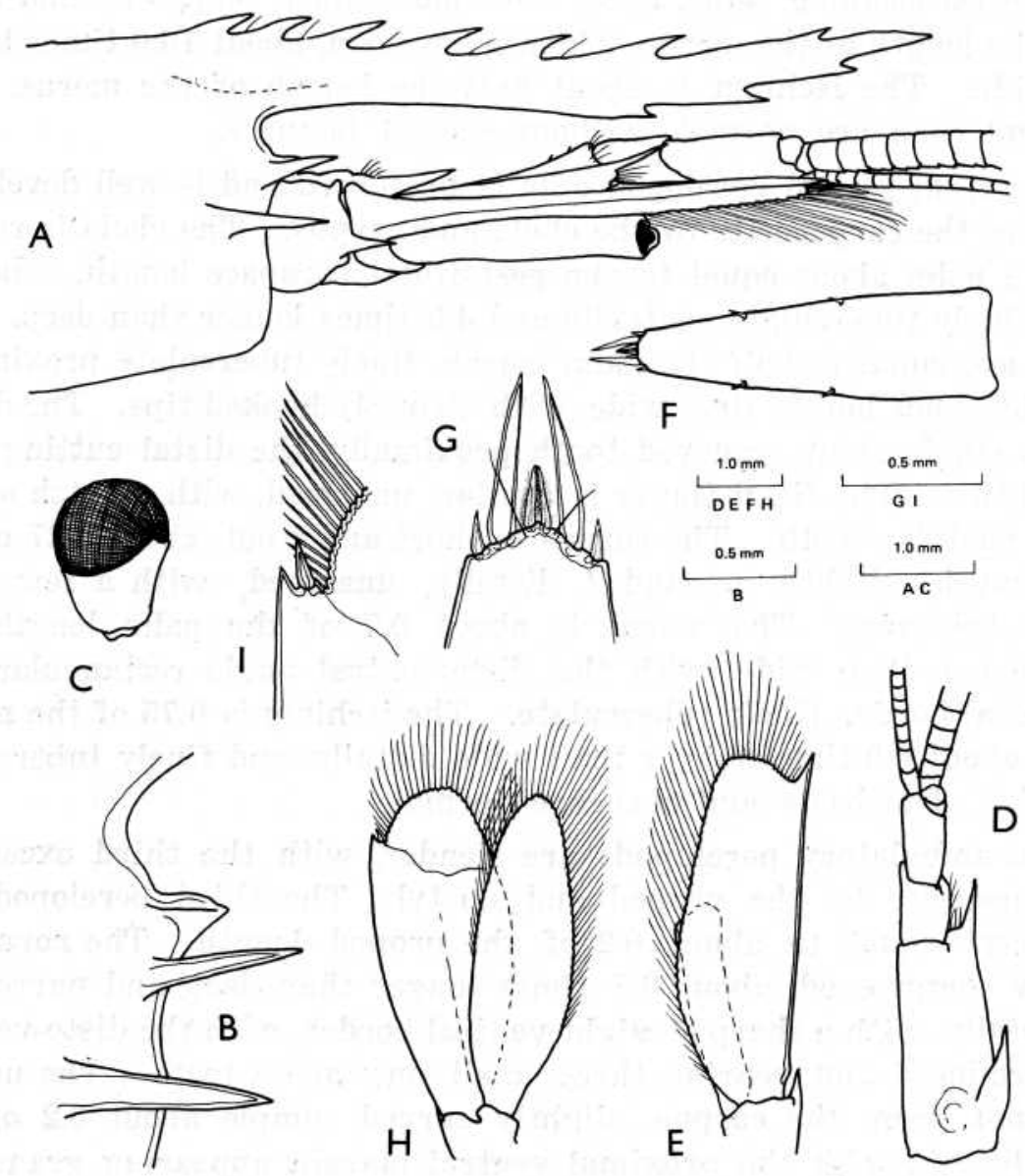

Fig. 2. Periclimenes dentidactylus sp. nov. A, anterior carapace, rostrum and antennal peduncles; B, interior orbital region, slightly oblique; C, eye, dorsal; D. antennular peduncle; E. antenna; F. telson; G. same, posterior spines; H. uropod; I. same, postero-lateral angle of exopod.

The first pereiopod is slender, exceeding the middle of the carpocerite by the carpus and chela, and the scaphocerite by the chela. The palm is slightly compressed, about 2.3 times longer than deep, with several groups of short serrated cleaning setae proximally. The fingers are subequal to the palm length, simple, with entire cutting edges, small hooked tips and numerous tufts of setae. The carpus is slender, about 1.25 times the length of the chela, widened distally, with a few 
disto-ventral cleaning setae, about 6.0 times longer than wide and about 0.9 of the length of the merus, which is uniform, about 10.0 times longer than wide. The dschium is about half the length of the meras. The basis and coxa are normal, without special features.

The right second pereiopod only is preserved and is well developed, exceeding the carpocerite by the chela and carpus. The chela is robust, with the palm about equal to the postorbital carapace length, subcylindrical, finely tuberculate ventrally and 4.0 times longer than deep. The fingers are equal to half the palm length, finely tuberculate proximally, about 4.8 times longer than wide, with strongly hooked tips. The dactyl bears a single stout recurved tooth proximally, the distal cutting edge being entire. The fixed finger is similar, unarmed, with a notch opposing the dactylar tooth. The carpus is short and stout, about 0.27 of the palm length, slightly expanded distally, unarmed, with a few small ventral tubercles. The merus is abou«t 0.7 of the pallm length, 7.0 times longer than wide, with the disto-ventral angle rectangular and the ventral border finely tuberculate. The ischium is 0.75 of the merus length, about 6.0 times longer than wide dlstally, and finely tuiberculate ventrally. The basis and coxa are normal.

The ambulatory pereiopods are slender, with the .third exceeding the carpocerite by the propod and dactyl. The third pereiopod has the dactyl equal to about 0.2 of the propod length. The corpus is strongly compressed, about 3.8 times longer than deep and narrowing only distally, with a sharp straight fventral border, with the disto-ventral angle produced and bearing three small very acute teeth. The unguis is distinct from the .corpus,, slightly curved, simple about 0.2 of the corpus length, with the proximal ventral margin, appearing granulate. Several short, robust setae are present disto-medially and disto-laterally on the corpus, with shorter similar setae along both sides of the sharp ventral edge. The propod is about 13.5 times longer than wide, uniform, with four single ventral spines anid three long, dorsally serrulate disto-ventral spines, with adjacent medial and lateral setae. The carpus is slightly longer than half the propod length, which is subequal to the merus. The ischium is 0.4 of the meral length. The basis and coxa are normal. The fourth and fifth pereiopods are similar, with the dentition at the disto-ventral angle of the dactylar corpus more acute, but with the propods less heavily spinose and the meri shorter and less robust.

The male first pleopod has the endopod well developed, atoout 4.2 times longer than wide, slightly expanded disto-medially. The proximal 


\section{A NEW DEEP WATER PONTONIINE}
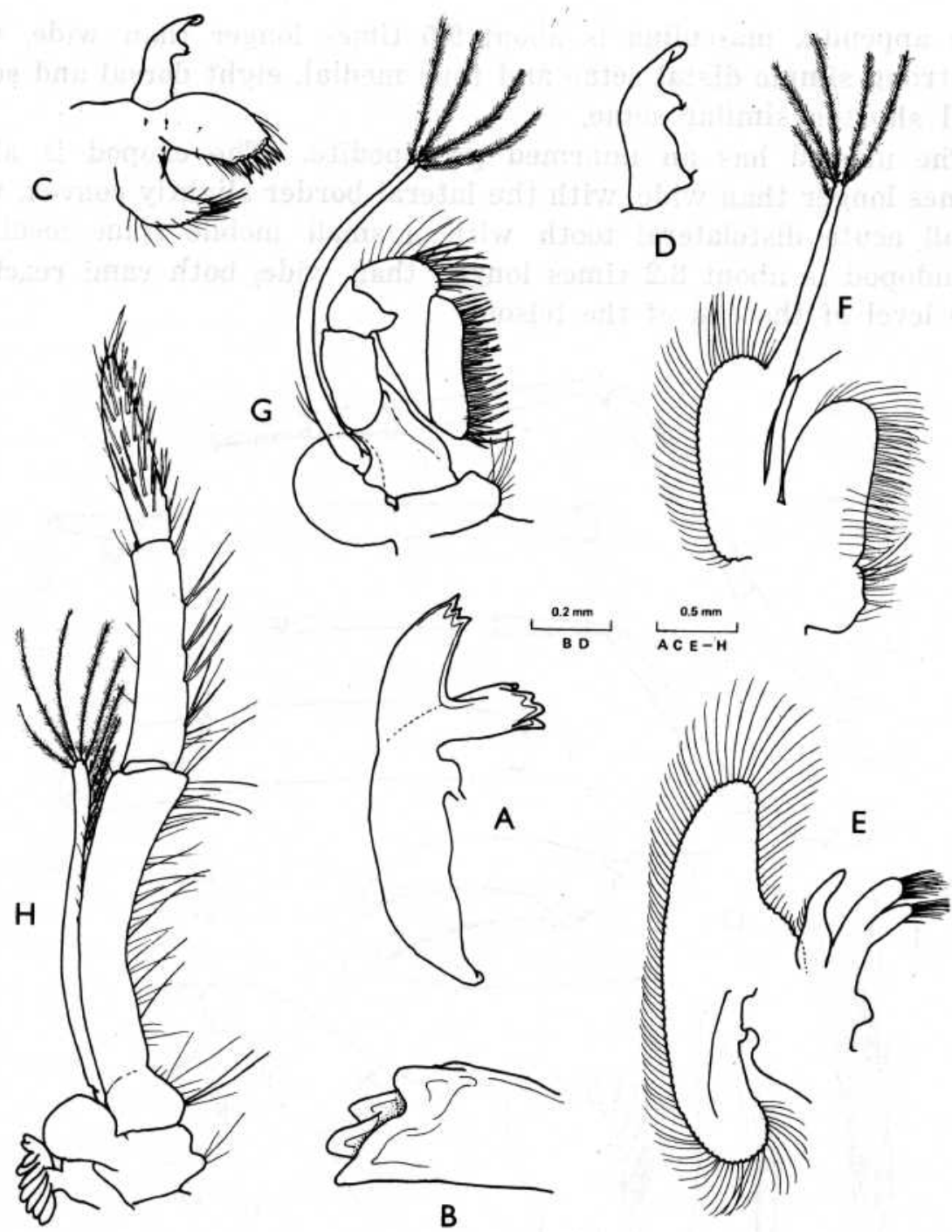

Fig. 3. Perictimenes dentidactylus sp. nov., mouthparts. A. mandible; B. molar process; C. maxillula; D. same, palp; E. maxilla; P. first maxillipeds; G. second maxilliped; H. third maxilliped.

third of the medial border bears four short, finely serrulate setae, the intermediate third seven short hooked setae and the distal third is bare. The disto-lateral border bears ten short plumose setae. The second pleopod has a well developed appendix masculiina, wtedh slightly exceeds the appendix interna and reaches 0.6 of the ramus length. The corpus 
of the appendix masculina is about 9-5 times longer than wide, with four strong simple distal setae and four medial, eight dorsal and seven lateral shorter similar setae.

The uropod has an unarmed protopodite. The exopod is about 2.5 times longer than wide, with thte lateral border slightly convex, with a small acute distolateral tooth with a small mobile spine medially. The endopod is about 3.2 times longer than wide, both rami reaching to the level of the end of the telson.

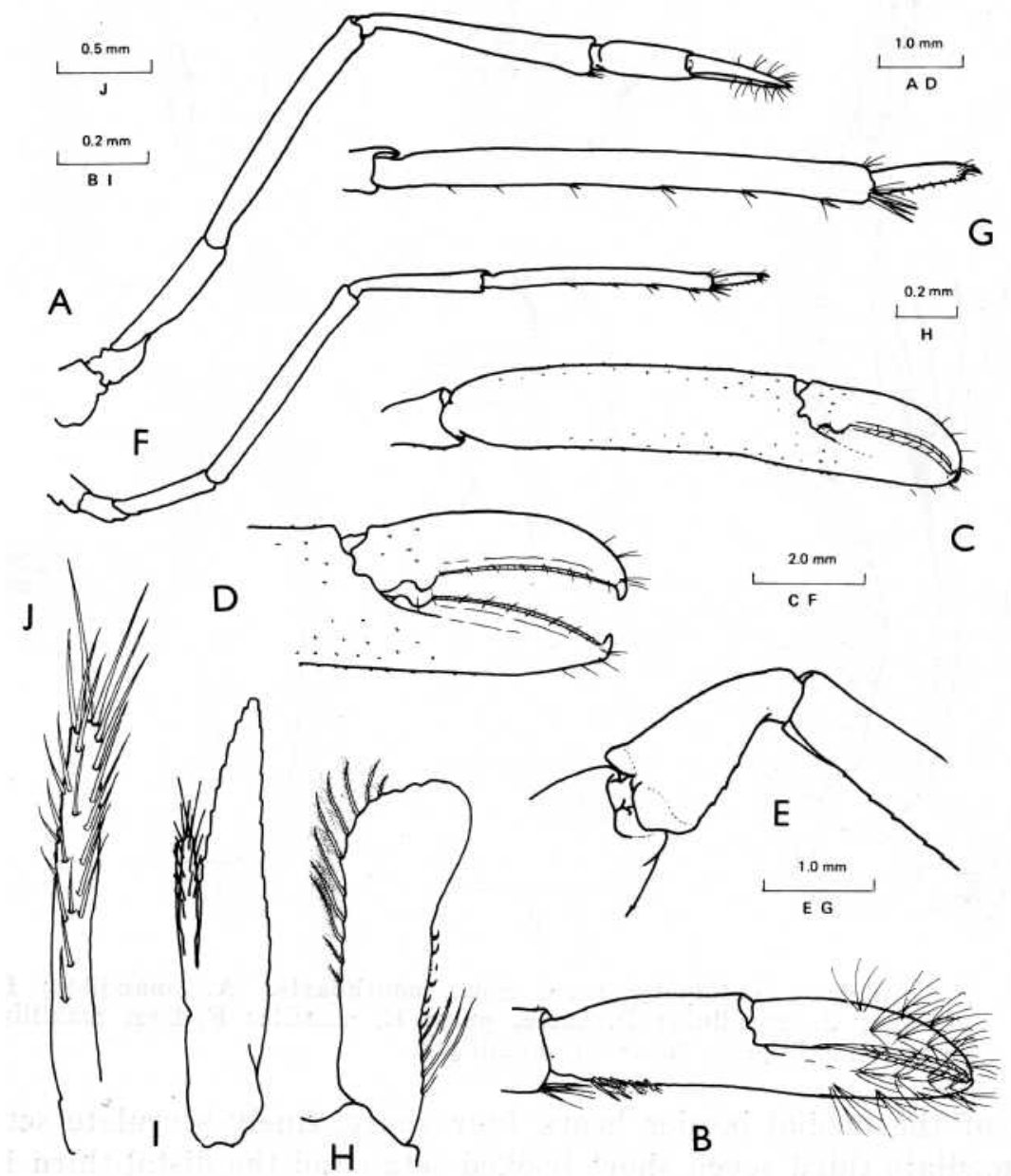

Fig.4. Periclimenes dentidactylus sp. nov. A. first pereiopod; B. same, chela, second pereiopod chela; D. same, fingers; E. same, carpus; F. third pereiopod; G. same, propod and dactyl; H. first pleopod, endopod; I. second pleopod, endopod; J. appendix masculina. 


\section{A NEW DEEP WATER PONTONIINE}

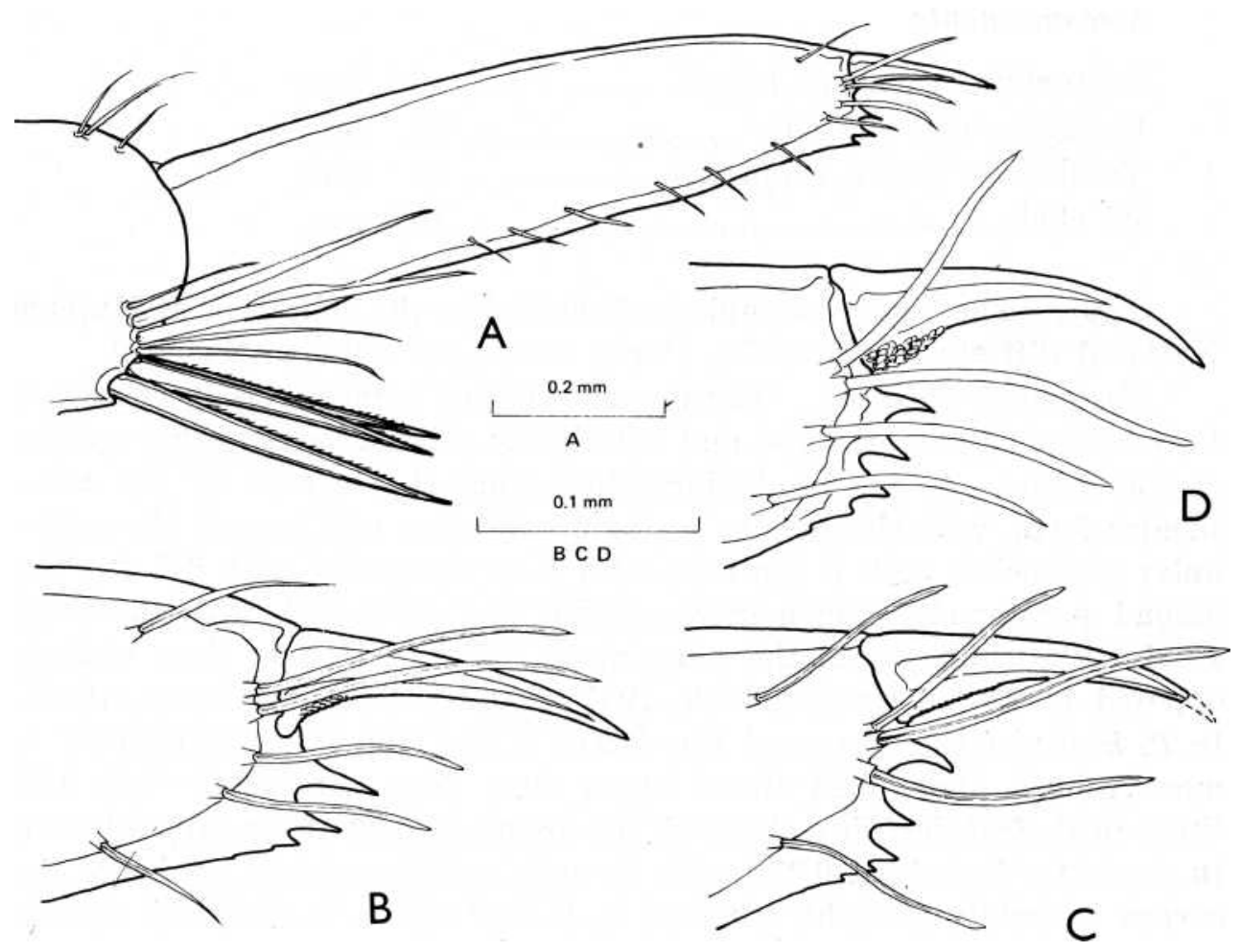

Fig. 5. Periclimenes dentidactylus sp. nov. A. dactyl of third pereiopod; B. distal carpus and unguis dactyl of third pereiopod; C. same, fourth pereiopod; D. same, fifth pereiopod.
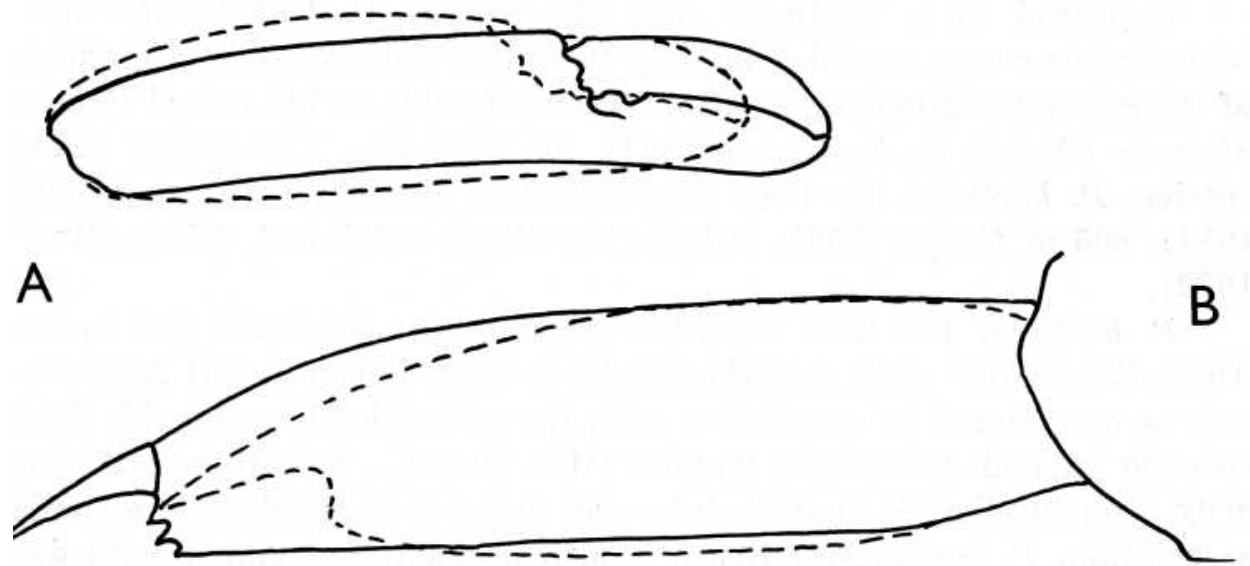

Fig. 6. Comparison of form of A, chela of second pereiopod and B, dactyl of ambulatory pereiopod in P. dentidactylus (full line) and P. hertwigi (dotted line), from HOLTHUIS (1952). 


\section{Measurements}

Postorbital carapace length.................. $6.5 \mathrm{~mm}$

Carapace and rostrum......................... $13 \quad \mathrm{~mm}$

Total body length (approx.) ................. 26 man

P2 chela

$10 \mathrm{~mm}$

Type. The single example is deposited in the collection of Museum National cTHisftoire Naturelle, Paris, catalogue number Na 5619.

Systematic Position. The present species is most closely related to Periclimenes hertwigi Balss and not closely related to any other species of the genus. It can be distinguished from $P$. hertwigi by the more slender form, with the slender rostrum extending well beyond the antennular peduncles, with a dentition of $7 / 3$ as compared with $6 / 1-2$. The second pereiopod is much more slender and elongated, with the chela finely tteberculate, with the palm about 4.0 times longer than wide as opposed to 2.7-3.0 times (KUBO, 1940; BALSS, 1914; HolTHUIS, 1952). In P. hertwigi the corpus of the dactyl of the ambulatory pereiopods is more robust, about 0.33 times longer than deep, contrasted with 0.25 times in $P$. dentidactylus, although the unguis in 0.23 of the carpus length in the latter but about 0.27 in the former, and the ventral border of the carpus is mainly straight, whereas in P. hertwigi it is distinctly convex.

\section{DISCUSSION}

Captured at a depth of over 590 meters, P. dentidactylus has a bathytmetric range exceeded by only two other Indo-West Pacific species of the genus Perticlimenes, P. alcocki Kemp (1922) at $743 \mathrm{~m}$ and P. Iaccadivensis (Alcock \& Anderson, 1894) at $1285 \mathrm{~m}$. The closely related species, P. hertwigi has been reported from depths of $120 \mathrm{~m}$ (BALSS, 1914), $305 \mathrm{~m}$ (KUBO 1940), $304 \mathrm{~m}$ (HolThUIS 1952) and $275 \mathrm{~m}$ (BRUCE 1972).

P. hertwigi has been recorded from Japan, Indonesia and eastern Australian waters only, and the specimen from Japanese and Australian waters were found in association with the echinothuriid echinoids Pharmosoma sp. and Araeosoma thetidis (H.L. Clark). It is therefore extremely probably that P. dentidmtylus will prove to be involved in a similar association. P. rectirostris Bruce is also probably associated with deep water echinothuriid echinoids (Eremopyga denudata) but does not appear to be closely related to P. dentidactylus or P, hertwigi, (BRUCE 1981), 


\section{A NEW DEEP WATER PONTONIINE}

\section{REFERENCES}

Alcock, A. and A.R. Anderson, 1894. An account of a Recent Collection of Deep Sea Crustacea from the Bay of Bengal and the Laccadive Sea. Natural History Notes from H.M. Indian Marine Survey Steamer "Investigator", Commander C.F. Oldham, R.N., commanding. Ser. II, No. 14. Journ. Asiat. Soc. Bengal, 63(2): 14M85, pi. 9.

BALss, H. 1914. Ostasiatische Decapoden II. Die Natantia und Reptantia. In: Doflein, F., Beitrage zur Naturgesehichte Ostasiens. Abh. Bayer Akad. Wiss., siippl. 2(10): 1-101, figs. 1-50, pi. 1.

BRUCE, A.J. 1972. Filophryxus dorsalis gen. nov. sp. nov., an unusual bopyrid parasite from eastern Australia. Parasitology, 65: 351-358, figs. 1-8.

BRUCE, A.J. ISSl. Decapod Crustacea: Pontoniinae. Resultats des campagnes MUSORSTOM. I. Philippines (18-28 mars, 1976). Mem. ORSTOM, 91: 189215, figs. 1-18.

Holthuis, L.B. 1952, Decapoda of the Siboga Expedition. Part XL The Palaemonidae (Collected by the Siboga and Snellius Expeditions with remarks on other species. II. Subfamily Pontoniinae. Siboga Exped. Mon., 39a 10;: 1252. figs. 1-110, tab. 1.

KEMP, S. 19122. Notes on Crustacea Decapoda in the Indian Museum, XV. Pontoniinae. Rec. Indian Mm. 24: 113-288, figs. 1-105, pis. 3-9.

KuBO, L. 1940. Studies in the Japanese Palaemonoid Shrimps. II. Pontoniinae. Journ. Imp. Fish, Inst, Tokyo, 34: 31-75, figs. 1-36. 